\title{
First Step Analysis in Quality Control -Volumetric Analysis
}

\author{
Mohamad Taleuzzaman* and Sadaf Jamal Gilani \\ Department of Pharmaceutical Chemistry, Glocal School of Pharmacy, Glocal University, Mirzapur Pole, Saharanpur 247121 U.P. India
}

Submission: February 20, 2017; Published: March 24, 2017

*Corresponding author: Mohamad Taleuzzaman, Assistant Professor, Glocal School of Pharmacy, Glocal University, Mirzapur Pole, Saharanpur 247121 U.P. India; Mobile: +91-7251892850; email: zzaman007@gmail.com

\begin{abstract}
Purpose of this article was to know the importance and significance of qualitative and quantitative analysis which has performed in quality control to authenticate the pharmaceutical products. In quality control analytical techniques are used like volumetric analysis which is one of the earlier steps of analysis. Broadly analysis is categorized in three parts- Titrimetric analysis, Chromatographic analysis and Instrumental analysis. Titrimetric analysis further study in three parts- volumetric analysis, Gravimetric analysis and Columnetric analysis. The selection of analytical method depends upon the physical state and nature of analyte. Titration is a quantitative chemical analysis method to estimate the unknown concentration of any substance, such as a raw material, substance or finished good. It is a widely used method that has been included in most of the key international pharmacopoeias and other regulations.
\end{abstract}

Keywords: Volumetric analysis; Quantitative; Raw material; Quality control

\section{Introduction}

In pharmaceutical industry the quality control is the check point for the raw material and as well as finished product. The incoming material in quality control is first checked by titrimetric method. Here the purity or standard of the material is confirmed by performing the qualitative and quantitative analysis. Even though volumetric titration is not a fully correct method since the result is affected by the titration equipment, the temperature and other laboratory conditions [1]. It is recommended to determine the titer of volumetric solutions to receive reliable and transparent results. This method result is influenced by the many factor like measuring method Instrument (instrument error/abrasion of the burette), Electrodes (electrode error/ alteration of electrodes), Handling (e.g. preparation of dilution), Balance (weighing error), Temperature Change of the volumetric solution because of influence through environmental oxygen, carbon dioxide, microorganism.

Titration can be finding to the origins of volumetric analysis, which started in the late eighteenth century, Study of analytical chemistry emerge in France and the first burette was made by Francois Antoine Henri Descroizilles (Table 1). The first book containing titration was titled Lehrbuch der chemischanalytischen Titrirmethode (Instructional Book of Titration Methods in Analytical Chemistry) and was published in 1855 in Germany by Gay-Lussac invented. The volumetric method which subsequently leads to the origin of term titration. The author of this book, Karl Freiderich Mohr, is also responsible for advancing the burette from a graduated cylinder- type instrument to a tool with a clamp at the bottom that is still used today. However Titrimetric has already been extensively used in past years, a literature search reveals that there are few recent methods that employ this technique for analysis of pharmaceuticals [2]. Some of the advantages of Titrimetric are short time of analysis and low cost of equipment required. However, titrimetric methods show lack of selectivity when compared to modern separation techniques such as HPLC or capillary electrophoresis, which probably led to the current disuse of titrimetric techniques. Below are listed some recent applications of this technique in pharmaceutical analysis.

Table 1: Titrimetric Analysis.

\begin{tabular}{|c|c|c|}
\hline Volumetric & Gravimetric & Coulometric \\
\hline $\begin{array}{l}\text { This method involves } \\
\text { the measurement } \\
\text { of volume of a } \\
\text { solution of known } \\
\text { concentration which } \\
\text { is used to determine } \\
\text { the concentration of } \\
\text { the analyte. }\end{array}$ & $\begin{array}{l}\text { This analysis is a } \\
\text { technique through } \\
\text { which the amount } \\
\text { of an analyte (the } \\
\text { ion being analyzed) } \\
\text { can be determined } \\
\text { through the } \\
\text { measurement of } \\
\text { mass. }\end{array}$ & $\begin{array}{l}\text { In a Couloumetric } \\
\text { method of analysis } \\
\text { we determine } \\
\text { an analyte's } \\
\text { concentration by } \\
\text { measuring the } \\
\text { potential of an } \\
\text { electrochemical } \\
\text { cell under static } \\
\text { conditions. }\end{array}$ \\
\hline
\end{tabular}




\section{Global Journal of Pharmacy \& Pharmaceutical Sciences}

This is the first quantitative analysis of APIs/Drugs/ Chemical substance that is performed in quality control as per the guideline of Pharmacopeias. Titration cover both volumetric and non-volumetric. The different titration has different principle of quantification [3]. According to the nature of analyte titration method select. The quantification of the analyte by titration may be not highly accurate and precise but the above methods are choice for the bulk drug analysis. For the better result in must be follow the WHO and ICH guidelines. Titrationa straightforward method with many application possibilities Because of their simplicity and accuracy, titration methods are used for a large proportion of the content determinations described in the monographs (Table 2). Metrohm has developed hundreds of titration methods with Metro sensors based on the U.S. Pharmacopeia (USP $<541>$ ) and European Pharmacopoeia. In the past titrimetric methods have been used for the determination of captopril [4], albendozole and gabapentin in commercial dosage forms. Sparfloxacin was determined by the nonaqueous titration method. In addition to its application in drug estimation titrimetry has been used in the past for the estimation of degradation products of the pharmaceuticals.

Table 2: some recent applications of this technique in pharmaceutical analysis.

\begin{tabular}{|c|c|c|c|}
\hline S.No. & Titration & Principle & APIs/Formulation \\
\hline 1. & Aqueous Acid-Base Titration & $\begin{array}{l}\text { Neutralization of acid -base, } \\
\text { determined end point by an } \\
\text { indicator or by titration curve }\end{array}$ & Benzbromarone \\
\hline 2. & Oxidation-Reduction Titration & $\begin{array}{l}\text { Redox reaction determined end } \\
\text { point by an indicator or by redox } \\
\text { titration curve. }\end{array}$ & $\begin{array}{l}\text { Captropril } \\
\text { Paracetamol } \\
\text { Sulfonamide }\end{array}$ \\
\hline 3. & Complexometric Titration & $\begin{array}{l}\text { Determination of metal ions by a } \\
\text { standard solution of complexing } \\
\text { agent using metal indicator or } \\
\text { titration curve to locate the end } \\
\text { point. }\end{array}$ & $\begin{array}{l}\text { Estimation of zinc in herbal } \\
\text { formulation Aphrodisiac capsule }\end{array}$ \\
\hline 4. & $\begin{array}{c}\text { Precipitation/Argentometric } \\
\text { Titration }\end{array}$ & $\begin{array}{l}\text { Generally using AgNO3 as an } \\
\text { standard solution at end point } \\
\text { insoluble precipitate are formed }\end{array}$ & Dimenhydrinate \\
\hline 5. & Non-aqueous Acid-Base Titration & $\begin{array}{l}\text { Titration without water analysis } \\
\text { of weak acid and weak base using } \\
\text { indicator or titration curve to } \\
\text { locate end point. }\end{array}$ & $\begin{array}{l}\text { Caffeine } \\
\text { Ketoconazole }\end{array}$ \\
\hline 6. & $\begin{array}{c}\text { Diazotization Titration or Nitrite } \\
\text { Titration }\end{array}$ & $\begin{array}{l}\text { Analyte that is primary aromatic } \\
\text { amine }\left(-\mathrm{NH}_{2}\right) \text { react with HONO } \\
\text { in presence of excess mineral or } \\
\text { inorganic acids. }\end{array}$ & $\begin{array}{l}\text { Dapsone } \\
\text { Procainamide } \\
\text { Hydrochloride }\end{array}$ \\
\hline 7. & Karl Fischer Titration & $\begin{array}{l}\text { Determination of Water in } \\
\text { pharmaceutical/organic } \\
\text { compound. Analysis based on } \\
\text { redox reaction }\end{array}$ & $\begin{array}{l}\text { Dapsone } \\
\text { Procainamide } \\
\text { Hydrochloride }\end{array}$ \\
\hline 8. & Kjeldahl's Method & $\begin{array}{l}\text { Determination of nitrogen in } \\
\text { organic compound based on acid } \\
\text {-base back titration }\end{array}$ & $\begin{array}{l}\text { Heparin Sodium } \\
\text { Urethan }\end{array}$ \\
\hline 9. & Oxygen Flask Combustion & $\begin{array}{l}\text { Analysis of various organic } \\
\text { compounds for elements } \\
\text { performed by adequate and } \\
\text { critical combustion of the organic } \\
\text { material in an atmosphere of } \\
\text { oxygen }\end{array}$ & $\begin{array}{l}\text { Idoxuridine } \\
\text { Niclosamide } \\
\text { Quindochlor }\end{array}$ \\
\hline 10. & Gravimetric Analysis & $\begin{array}{l}\text { Element or Ion in a substance } \\
\text { is usually determined from the } \\
\text { weight of the precipitate }\end{array}$ & Determination metal impurities \\
\hline 11. & Gasometric Assay Method & $\begin{array}{l}\text { Refers to the measurement of } \\
\text { gases specifically in a sample or a } \\
\text { mixture. }\end{array}$ & $\begin{array}{l}\text { Crbondioxide } \\
\text { Cyclopropane }\end{array}$ \\
\hline
\end{tabular}




\section{Quality Management System -Titration}

In analytical study it is necessary to determine the results with high accuracy. Whatever methods used must be adapted to the problem. With suitable working procedures a reproducible and traceable documentation of results must be present. Here it is important to describe as a whole how a quality management system (QMS) for titrimetric analyses must be arranged [5]. The actual circumstances and requirements have to be think carefully, who titrates what, by which means and with which accuracy? This must be documented in a traceable way. Some time in wrong way quality management is sometimes understood asThe request of usability data and additional quality relevant data per certificate from the reagent manufacturer, the presentation of technical tolerances of the instrument available from the manufacturer.QMS maintain by consider only a small basis for comprehensive analytical result.

1. Application data of standard solutions, supplied by the manufacturer, are only valid for originally closed containers. After opening other influences play a role.

2. The titter indicated on the certificate refers only to the standard solution and is determined independently of the instrument. Specific properties of the analytical instrument used cannot be considered. The indicated titter can directly be applied by the user only with certain limitations.

3. Technical data of analytical instruments can only be used in a quality-related way when they are confirmed by regular control. The obvious prerequisite is periodical maintenance and service.

\section{Conclusion}

As the above study it is finding that the volumetric analysis plays a big role in analytical field either in direct way or in indirect way. In spite lack of accuracy in result this method result surely maintain the standard of the quality of the product.

\section{References}

1. Robert L Martin (2010) Center for Food Safety and Applied Nutrition. Food and Drug Administration pp 1-166.

2. Leung VW, Shalansky SJ, Lo MK, Jadusingh EA (2009) Prevalence of use and the risk of adverse effects associated with complementary and alternative medicine in a cohort of patients receiving warfarin. Ann Pharmacother 43(5): 875-81.

3. Glynn RJ, Ridker PM, Goldhaber SZ, Zee RY, Buring JE (2007) Effects of random allocation to vitamin E supplementation on the occurrence of venous thromboembolism: report from the Women's Health Study. Circulation 116(13): 1497-503.

4. Meydani SN, Meydani M, Blumberg JB, Leka LS, Siber G, et al. (1997) Vitamin E supplementation and in vivo immune response in healthy elderly subjects: A randomized controlled trial. JAMA 277(17): 13801386.

5. Corrigan JJ, Marcus FI (1974) Coagulopathy associated with vitamin E ingestion. JAMA 230(9): 1300-1301.

6. Kim JM, White RH (1996) Effect of vitamin E on the anticoagulant response to warfarin. Am J Cardiol 77(7): 545-6.

7. Knapp HR (1997) Dietary fatty acids in human thrombosis and hemostasis. Am J Clin Nutr 65(5): 1687-1698.

8. Turpeinen AM, Mutanen M (1999) Similar effects of diets high in oleic or linoleic acids on coagulation and fibrinolytic factors in healthy humans. Nutr Metab Cardiovasc Dis 9(2): 65-72.

9. Benito P, Nelson GJ, Kelley DS, Bartolini G, Schmidt PC, et al. (2001) The effect of conjugated linoleic acid on platelet function, platelet fatty acid composition, and blood coagulation in humans. Lipids 3(3)6: 221-227.

10. Hunter KA, Crosbie LC, Horgan GW, Miller GJ, Dutta-Roy AK (2001) Effect of diets rich in oleic acid, stearic acid and linoleic acid on postprandial haemostatic factors in young healthy men. Br J Nutr 86(2): 207-215.

11. Allman-Farinelli MA, Hall D, Kingham K, Pang D, Petocz P, et al (1999) Comparison of the effects of two low fat diets with different alpha-linolenic: linoleic acid ratios on coagulation and fibrinolysis. Atherosclerosis 142(1): 159-168.

12. Lacut K, Ayme-Dietrich E, Gourhant L, Poulhazan E, Andro M, et al (2012) Impact of genetic factors (VKORC1, CYP2C9, CYP4F2 and EPHX1) on the anticoagulation response to fluindione. $\mathrm{Br} \mathrm{J}$ Clin Pharmacol 73(3): 428-436.

Your next submission with Juniper Publishers will reach you the below assets

- Quality Editorial service

- Swift Peer Review

- Reprints availability

- E-prints Service

- Manuscript Podcast for convenient understanding

- Global attainment for your research

- Manuscript accessibility in different formats

( Pdf, E-pub, Full Text, Audio)

- Unceasing customer service

Track the below URL for one-step submission https://juniperpublishers.com/online-submission.php 